\title{
Interleukin-1 Receptor Antagonist (ILIRA) and Interleukin-4 (IL4) Genes Variable Number Tandem Repeats (VNTRs) Are Associated with Adiposity in Malaysian Subjects
}

\author{
Yung-Yean Kok, Hing-Huat Ong and Yee-How Say * \\ Department of Biomedical Science, Faculty of Science, Universiti Tunku Abdul Rahman (UTAR) Kampar \\ Campus, Jalan Universiti, Bandar Barat, 31900 Kampar, Perak, Malaysia \\ *Corresponding author: sayyh@utar.edu.my; Tel: +605-4688888 ext. 4505; Fax: +605-4661676
}

\begin{abstract}
ILIRA intron 2 86-bp repeat and IL4 intron 3 70-bp repeat are VNTRs that have been associated with various diseases, but their role in obesity is elusive. The objective of this study was to investigate the association of ILIRA and IL4 VNTRs with obesity and adiposity in 315 Malaysian subjects (128 M/187 F; 23 Malays/251 ethnic Chinese/41 ethnic Indians). The allelic distributions of ILIRA and IL4 were significantly different among ethnicities, and the alleles were associated with total body fat (TBF) classes. Individuals with ILIRA I/II genotype or allele II had greater risk of having higher adiposity - even after controlling for ethnicity [Odds Ratio (OR) of I/II genotype $=12.21(\mathrm{CI}=2.54,58.79 ; p=0.002)$; II allele = $5.78(\mathrm{CI}=1.73,19.29 ; p=0.004)]$. However, IL4 VNTR B2 allele was only significantly associated with overall adiposity status before adjusting for ethnicity [OR $=1.53$ (CI $=1.04$, 2.23; $p=0.03)$ ]. TBF was also significantly higher in those with IL1RA II allele compared with I allele $(31.79 \pm 2.52 v s .23 .51 \pm 0.40 ; p=0.005)$. Taken together, ILIRA intron 3 VNTR seems to be a genetic marker for overall adiposity status in Malaysian subjects.
\end{abstract}

Keywords: Interleukin-1 receptor antagonist (IL-1Ra); Interleukin-4 (IL-4); Variable Number Tandem Repeat (VNTR); obesity; adiposity; Malaysia.

\section{Introduction}

The prevalence of obesity worldwide is rising at alarming rate and has been described as a global pandemic. Malaysia has one of the highest rates of obesity in Asia-Pacific, where the combined prevalence of overweight and obesity was $43.8 \%$ and $48.6 \%$ among men and women above 20 years, respectively [1]. Obesity is closely associated with chronic and lowgrade inflammation in the adipose tissue, signified by a lower level of anti-inflammatory cytokines and higher level of pro-inflammatory cytokines, which in turn differentially activate adipose-tissue macrophages (ATMs) [2]. Specifically, anti-inflammatory cytokines interleukin (IL)-13, IL-4 and IL-10 stimulate the alternatively-activated ATMs (M2) in lean persons, while obesity induces a shift to the classically-activated ATMs (M1) due to stimulation by pro-inflammatory cytokines TNF- $\alpha$, IL-1 $\beta$ and IL-6 [3]. 
Interleukin-1 receptor antagonist (IL-1Ra), also known as IL-1RN, is an endogenous competitive inhibitor of pro-inflammatory IL-1 $\alpha$ and IL-1 $\beta$ [4], and is highly secreted by the white adipose tissue (WAT) [5]. IL-1ra is a pro-adipogenic factor as $I L-1 R a$ knockout mice have reduced adipose storage, impaired adipogenesis and decreased in adipocyte size [6], while its level is increased in the serum of obese patients, correlating with body mass index (BMI) and insulin resistance [7]. The human IL-1ra gene (ILIRA or IL1RN) has a Variable Number Tandem Repeat (VNTR) polymorphism within intron 2 due to variation in the number of copies of an 86 bp sequence. To date, six distinct alleles corresponding to 1, 2, 3, 4, 5 and 6 copies of the repeat sequence have been identified [8]. The 4-repeat (allele I) and 2repeat (allele II) are most frequently found in the general population while the other four alleles (allele III, IV, V and VI) are rarely observed [9]. This VNTR, particularly those homozygous for allele II, has been variably associated with various conditions such as obesity, inflammatory bowel disease and coronary artery disease [reviewed in 10] in different ethnic populations worldwide.

IL-4, secreted by activated Th2 lymphocytes, basophils, and mast cells, executes many biological roles such as induction of Th2 differentiation, immunoglobulin class switching, and $B$ cell proliferation [11]. In animal studies, diet-induced obese mice had increased splenic lymphocytes production of IL-4 [12], rats receiving visceral fat removal surgery had decreased serum IL-4 [13] and mice treated with IL-4 had improved insulin sensitivity, glucose tolerance while lipid accumulation in adipose tissues was inhibited [14]. These suggest that IL-4 may participate in the processes of diet-induced obesity and metabolism. Similar with IL1RA, IL4 has a 70-bp VNTR polymorphism within intron 3, and two common alleles are B1 and B2 that have two and three tandem repeats, respectively [15]. There have been several reports on the association between the VNTR B1 allele and mostly inflammatory diseases, such as multiple sclerosis [16], rheumatoid arthritis [17] and systemic lupus erythematosus [18]. With regards to obesity, there are limited studies on this VNTR, where two studies showed no association $[19,20]$.

Since the association of ILIRA and IL4 VNTRs with obesity and its related parameters is still elusive especially in Asians, the objectives of this study are therefore to investigate the distribution of ILIRA and IL4 VNTRs genotypes and alleles, and to determine whether they are associated with overall obesity (as measured by BMI), central adiposity (as measured by waist circumference, WC) and overall adiposity (as measured by total body fat, TBF) in Malaysian subjects. 


\section{Materials and methods}

\section{Subjects}

A convenience sampling method was adopted for this study. Questionnaire and sample collection was carried out among unrelated and non-overlapping 315 subjects comprising of three cohorts (128 or $40.63 \%$ males and 187 or $59.37 \%$ females): 1) 69 Universiti Tunku Abdul Rahman (UTAR) Setapak Campus students and residents of Setapak and Petaling Jaya were recruited from October 2009 - February 2010 [32 males and 37 females; 23 Malays, 40 Chinese and 6 Indians; mean age 28.49 years]; 2) 20 UTAR Perak Campus students were recruited from October 2011 - January 2012 [9 males and 11 females; all Chinese; mean age 19.90 years]; 3) UTAR Perak Campus students were recruited from January 2013 - May 2013 [87 males and 139 females; 192 Chinese and 34 Indians; mean age 21.30 years]. The ethnicities of the subjects were self-identified. All subjects were pooled together for data analysis. The demographic and anthropometric characteristics of the 315 subjects are as shown in Table 1. There was no significant association between gender and the demographic and anthropometric classes. This study has received ethical approvals from the UTAR Scientific and Ethical Review Committee (SERC). All subjects signed informed consent forms, and the study was conducted in accordance with the Declaration of Helsinki (amended in Brazil, 2013).

\section{Questionnaire and anthropometric measurements}

Clinical and anthropometric measurements namely systolic blood pressure (SBP), diastolic blood pressure (DBP), pulse rate, waist circumference (WC), hip circumference (HC), waistto-hip ratio (WHR), weight, height, body mass index (BMI) and total body fat (TBF) were measured as described in our previous studies [21, 22]. The cut-off points for obesity, overall adiposity (TBF) and central adiposity (WHR) were $\geq 25 \mathrm{~kg} / \mathrm{m}^{2}$ [23], 20\% (males) or 30\% (females) [24] and 0.90 (males) or 0.85 (females)[25], respectively.

\section{DNA extraction and genotyping}

Participants were asked to rinse their vigorously with $5 \mathrm{ml}$ of $3 \%$ sucrose solution for $1 \mathrm{~min}$ and the mouthwash samples were preserved in $3 \mathrm{ml} \mathrm{TNE}$ buffer $[17 \mathrm{mM}$ Tris/ $\mathrm{HCl}$ (ph 8.0), $50 \mathrm{mM} \mathrm{NaCl}, 7 \mathrm{mM}$ EDTA]. DNA extraction protocol was then conducted following the protocol as outlined previously [26]. The ILIRA and IL4 VNTRs were genotyped by Polymerase Chain Reaction using the primers, reagents, and conditions adopted from [27] or [20], respectively, with minor modifications. PCR was performed in a $20 \mu \mathrm{L}$ total reaction mixture containing $1 \times$ PCR buffer $\left(\mathrm{NH}_{4}\right)_{2} \mathrm{SO}_{4}$ without $\mathrm{MgCl}_{2}$ (PhileKorea, Korea), $1.5 \mathrm{mM}$ $\mathrm{MgCl}_{2}, 0.2 \mathrm{mM}$ dNTPs (PhileKorea, Korea), $0.5 \mu \mathrm{M}$ of forward primer, $0.5 \mu \mathrm{M}$ of reverse primer, $100 \mathrm{ng}$ of DNA template, $0.5 \mathrm{U}$ of Taq polymerase (PhileKorea, Korea), and an 
appropriate volume of sterile deionized water to top up. The PCR amplification protocol was carried out using the Bio Rad PCR machine (model T100 ${ }^{\mathrm{TM}}$ Thermal Cycler) (Eppendorf, Germany) which began with initial denaturation at $95^{\circ} \mathrm{C}$ for $5 \mathrm{~min}$, followed by 30 cycles of denaturation at $94^{\circ} \mathrm{C}$ for $30 \mathrm{sec}$, annealing at $60^{\circ} \mathrm{C}$ for $30 \mathrm{sec}$ (for $I L 1 R A$ ) or $66^{\circ} \mathrm{C}$ for $45 \mathrm{sec}$ (for $I L 4$ ), extension at $72^{\circ} \mathrm{C}$ for $30 \mathrm{sec}$ (for $I L 1 R A$ ) or $1 \mathrm{~min}$ (for $I L 4$ ), and final extension at $72^{\circ} \mathrm{C}$ for $10 \mathrm{~min}$. PCR products were electrophoresed on either $1.5 \%$ (for $I L 1 R A$ ) or $3 \%$ (for $I L 4)$ agarose gel, then stained with ethidium bromide and visualized under UV light after electrophoresis. The sizes of the bands for ILIRA alleles were I: $410 \mathrm{bp}$, II: $240 \mathrm{bp}$; IL4 alleles were B2: $253 \mathrm{bp}, \mathrm{B} 1: 183 \mathrm{bp}$. Three genotypes from each VNTR were verified by DNA sequencing of PCR products (First BASE Laboratories Sdn. Bhd., Malaysia).

\section{Statistical analysis}

Statistical analysis was carried out using the IBM SPSS Statistics software version 16.0 (IBM, NY, USA). Allelic frequencies were estimated by gene counting and the distribution of genotypes was tested for Hardy-Weinberg equilibrium using the Chi-square $\left(\chi^{2}\right)$ test. Data for continuous variables were presented as adjusted means \pm standard error of the mean (SEM) and as frequency for categorical variables. The normality of distributions of continuous variables was tested with the Kolmogorov-Smirnov test and variables that were not distributed normally were log-transformed prior to statistical analysis. Genotype and allele frequencies of the polymorphism were assessed for association with demographic and anthropometric classes using Pearson's $\chi^{2}$ test or Fischer's exact test. Logistic regression analysis (enter method) was performed for overall adiposity status with adjustment for covariate ethnicity. Analysis of covariance using the univariate General Linear Model with adjustment for covariate ethnicity was performed for anthropometric measurements and blood pressures. A $p$-value of less than 0.05 was considered as statistically significant.

\section{Results}

Table 2 shows the genotype and allele distribution of IL1RA and IL4 VNTRs, which did not deviate from the Hardy-Weinberg equilibrium, and are categorized under different demographic and anthropometric classes. The overall minor allele frequencies (MAFs) of $I L 1 R A$ and IL4 were 0.02 and 0.25 , respectively. The allelic distribution of ILIRA was significantly different between Chinese and Indians and for $I L 4$, it was significantly different between all ethnicities (Table 2). ILIRA and IL4 allele distributions were also significantly associated with TBF class, but not other demographic and anthropometric classes. Genotype distribution of IL4 was also not significantly associated with gender, ethnicity, BMI, WC and TBF classes.

Since TBF class was significant for both ILIRA and IL4 VNTRs, logistic regression analysis was carried out to study the association of $I L-1 R a$ and $I L-4$ VNTRs with overall adiposity 
(TBF) status (Table 3). As TBF was significantly different between ethnicities (data not shown), ethnicity was considered as a covariate. The IL1RA VNTR genotype and allele were significantly associated with overall adiposity before and after adjusting for ethnicity. Particularly, subjects with heterozygous I/II genotype had 14.45 times higher risk to have high adiposity compared with subjects with homozygous I/I genotype, while those with allele II had 6.81 times higher risk to have high adiposity compared with subjects with allele I. After controlling for ethnicity, the association of ILIRA genotype and allele with adiposity status remained significant with I/II subjects having 12.21 times higher risk compared with I/I subjects, and II subjects having 5.78 times higher risk compared with I subjects. However, IL4 VNTR B2 allele was only significantly associated with overall adiposity status before adjusting for ethnicity $[\mathrm{OR}=1.53(\mathrm{CI}=1.04,2.23 ; p=0.03)]$, and this association was abolished after controlling for ethnicity $[\mathrm{OR}=1.13(\mathrm{CI}=0.74,1.74 ; p=0.57)]$ (Table 3$)$.

Indeed, covariate analysis of variance after controlling for ethnicity also showed similar result, where subjects carrying IL1RA II allele had 8.28\% significantly higher TBF than the those with I allele (Table 4). All other anthropometric measurements and blood pressures were not significantly different between ILIRA and IL4 VNTR alleles.

\section{Discussion}

In this study, as expected, only allele I and allele II of IL4 VNTR can be found. The others alleles are too rare to be found in most of the populations [27]. The IL4 VNTR is considered a rare genetic polymorphism, as the MAF was 0.02 (less than 0.05 ). There is significant proof to show that IL4 VNTR is highly influenced by ethnicity [reviewed in 27]. A study in 19 Chinese populations found out that allele I had higher frequency than allele II, which were 0.913 and 0.064 , respectively, indicating that the prevalence of allele 1 in China was significantly higher, and the prevalence of allele 2 was significantly lower, than those in American and European Caucasians [28]. Similarly in African and African-American people, the frequency of allele 2 homozygotes is considerably lower than that in the Caucasian populations [29]. Alike with $I L 4$, the allele and genotype frequencies for ILIRA VNTR in our population are strikingly different from those of the Caucasian population [30 - 33], with our MAF of 0.25 being more similar to the Japanese population (MAF $=0.33)$ [34] and a previous Malaysian study $(\mathrm{MAF}=0.37)[35]$.

IL-1Ra serum levels are increased in human obesity, and are under strong genetic control [5], partly by the $I L R I A$ VNTR polymorphism. Indeed, $I L-1 R a$ allele II has a clear influence on IL-1Ra circulating levels since in normal human subjects, its carrier individuals had 10-fold higher levels than the non-carrier individuals $(745 \mathrm{ng} / \mathrm{ml} v s .627 \mathrm{pg} / \mathrm{ml})$ [36]. With regards to obesity, two previous Asian studies with relatively small sample sizes found no significant association of ILIRA VNTR with BMI in Koreans $(N=261)[37]$ and North Indians $(N=$ 103)[38]. Similarly, our study found no association with BMI value or overall obesity status, 
but ILIRA VNTR was associated with both TBF value and overall adiposity status. The $I L 1 R A$ VNTR may have functional significance as the repeated sequence contains possible binding sites for transcription factors [9]. A review by Witkin et al. 2002 [10] summarized that individuals homozygous for allele II have a more prolonged and more severe proinflammatory immune response than persons with other ILIRA genotypes, which might be beneficial when combating infectious agents [39] or neoplasms [40], but is detrimental for those with chronic inflammatory conditions [41] or who are pregnant [42].

The IL4 VNTR which is located in IL4 intron 3 could be a functional polymorphism as it could affect mRNA splicing - leading to different splice variants [43]. Indeed, the B2 allele has been associated with reduced amount of peripheral Th cells which produced IL-4 [34]. Our study showed that this VNTR was associated with overall adiposity status (TBF class), but not with TBF value after adjustment for ethnicity. However, consistent with two previous studies which showed no association of this VNTR with obesity status in North Indians [19] and Turkish [20], we found no association with both BMI value and overall obesity status. The role of IL-4 in modulating adipogenesis has been established by previous studies. Tsao et al. (2014) [44] showed IL-4 inhibited adipogenesis via STAT6 pathway or by influencing the cell proliferation at the mitotic clonal expansion phase. IL-4 also enhances lipolysis via the PKA pathway in mature adipocytes [44]. Other study carried out by Rao et al. (2014) [45] revealed that IL-4 signaling activated macrophages in WAT, leading to the production of nervous system molecules required for converting WAT to beige fat. Taken together, the direct functional significance of ILIRA and IL4 VNTRs, particularly on affected tissues in obesity (like adipose tissue) and other metabolic disease (like type 2 diabetes mellitus) warrants further investigation.

Limitations of the present study include the small sample size of Malay and Indian subjects, and the lack of other indigenous ethnic groups especially from East Malaysia (Sabah and Sarawak); hence the results from this study may not be fully representative of the general Malaysian population. Other common genetic variants like the $I L-1 \beta$ promoter region and exon-5 and IL4 -590 T/C single nucleotide polymorphisms, which were not screened in this study, could have association with obesity and its related parameters. The direct phenotypegenotype correlation could also be determined by measuring the serum levels of IL-1Ra and IL-4 using ELISA in the future.

Obesity results in a pro-inflammatory state which involves the release of cytokines and adipokines by adipose tissue. Indeed, the main finding of this study shows that VNTR genetic polymorphisms in two genes - ILIRA and IL4 encoding for anti-inflammatory cytokines IL$1 \mathrm{Ra}$ and IL-4, respectively, are associated with overall adiposity status (TBF) in Malaysian subjects. ILIRA VNTR shows a more prominent effect, as TBF was significantly higher in those with ILIRA II allele compared with I allele, after controlling for ethnicity. Individuals 
with IL4 VNTR B2 allele had higher risk of having higher adiposity, but the association was abolished after controlling for ethnicity. Taken together, IL1RA intron 3 VNTR seems to be a genetic marker for overall adiposity status in Malaysian subjects.

\section{Acknowledgements}

This work was supported by grant from the Department of Biomedical Science, UTAR. We gratefully acknowledge all the volunteers who have participated in this study.

\section{Declaration of Interest}

We declare no conflicts of interest.

\section{References}

1. Ng M, Fleming T, Robinson M, et al (2014) Global, regional, and national prevalence of overweight and obesity in children and adults during 1980-2013: a systematic analysis for the Global Burden of Disease Study 2013. Lancet 384:766-781.

2. Hotamisligil GS (2006) Inflammation and metabolic disorders. Nature 444:860-867.

3. Shu CJ, Benoist C, Mathis D (2012) The immune system's involvement in obesity-driven type 2 diabetes. Semin Immunol 24:436-442.

4. Perrier S, Darakhshan F, Hajduch E (2006) IL-1 receptor antagonist in metabolic diseases: Dr Jekyll or Mr Hyde? FEBS Lett 580:6289-6294.

5. Juge-Aubry CE, Somm E, Giusti V, Pernin A, Chicheportiche R, Verdumo C, RohnerJeanrenaud F, Burger D, Dayer JM, Meier CA (2003) Adipose tissue is a major source of interleukin-1 receptor antagonist: upregulation in obesity and inflammation. Diabetes 52:1104-1110.

6. Somm E, Henrichot E, Pernin A, Juge-Aubry CE, Muzzin P, Dayer JM, Nicklin MJ, Meier CA (2005) Decreased fat mass in interleukin-1 receptor antagonist-deficient mice: impact on adipogenesis, food intake, and energy expenditure. Diabetes 54:3503-3509.

7. Meier CA, Bobbioni E, Gabay C, Assimacopoulos-Jeannet F, Golay A, Dayer JM (2002) IL-1 receptor antagonist serum levels are increased in human obesity: a possible link to the resistance to leptin? J Clin Endocrinol Metab 87:1184 -1188.

8. Vamvakopoulos JE, Taylor CJ, Morris-Stiff GJ, Green C, Metcalfe S (2002) The interleukin-1 receptor antagonist gene: a single-copy variant of the intron 2 variable number tandem repeat (VNTR) polymorphism. Eur J Immunogenet 29:337- 340.

9. Tarlow JK, Blakemore AI, Lennard A, Solari R, Hughes HN, Steinkasserer A, Duff GW (1993) Polymorphism in human IL-1 receptor antagonist gene intron 2 is caused by variable numbers of an 86-bp tandem repeat. Hum Genet 91:403-404.

10. Witkin SS, Gerber S, Ledger WJ (2002) Influence of Interleukin-1 receptor antagonist gene polymorphism on disease. Clin Infect Dis 34:204-209. 
11. Nelms K, Keegan AD, Zamorano J, Ryan JJ, Paul WE (1999) The IL-4 receptor: signaling mechanisms and biologic functions. Annu Rev Immunol 17:701-738.

12. Mito N, Hosoda T, Kato C, Sato K (2000) Change of cytokine balance in diet-induced obese mice. Metabolism 49:1295-1300.

13. Borst SE, Conover CF, Bagby GJ (2005) Association of resistin with visceral fat and muscle insulin resistance. Cytokine 32: 39-44.

14. Chang YH, Ho KT, Lu SH, Huang CN, Shiau MY (2012) Regulation of glucose/lipid metabolism and insulin sensitivity by interleukin-4. Int J Obes (Lond) 36:993-998.

15. Mout R, Willemze R, Landegent JE (1991) Repeat polymorphisms in the interleukin4(IL-4). Nucleic Acid Res 19: 3763.

16. Olsson T (1995) Cytokine-producing cells in experimental autoimmune encephalomyelitis and multiple sclerosis. Neurology 45: S11-S15

17. Buchs N, Silvestri T, di Giovine FS Chabaud M, Vannier E, Duff GW, Miossec P (2000) IL-4 VNTR gene polymorphism in chronic polyarthritis. The rare allele is associated with protection against destruction. Rheumatology 39:1126-1131

18. Wu MC, Huang CM, Tsai JJ, Chen HY, Tsai FJ (2003) Polymorphisms of the interleukin4 gene in Chinese patients with systemic lupus erythematosus in Taiwan. Lupus 12:21-25

19. Sobti RC, Maithil N, Thakur H, Sharma Y, Talwar KK (2010) VEGF and IL-4 gene variability and its association with the risk of coronary heart disease in north Indian population. Mol Cell Biochem 341:139-148.

20. Tekcan A, Yigit S, Rustemoglu A, Gurel C, Sahin S, Tasliyurt T (2013) The investigation of obesity susceptibility with IL-4 gene intron 3 VNTR and IL-6 gene -597G/A polymorphisms in a Turkish population. Int J Hum Genet 13:209-213.

21. Yiew SK, Khor LY, Tan ML, Pang CL, Chai VY, Kanachamy SS, Say YH (2010) No association between peroxisome proliferator-activated receptor and uncoupling protein gene polymorphisms and obesity in Malaysian university students. Obes Res Clin Pract 4:e247-e342.

22. Chan PM, Fan SH, Say YH (2011) No association of Peptide Tyrosine-Tyrosine (PYY) gene variant R72T with obesity in the Kampar health clinic cohort, Malaysia. Mal J Nutr 17:201-212.

23. WHO/IOTF/IASO (2000) The Asia-Pacific perspective: redefining obesity and its treatment, Hong Kong: World Health Organization, International Obesity Task Force, International Association for the Study of Obesity.

24. Omron (n.d.) Omron KARADA Scan Body Composition \& Scale (HBF-362), Japan: Omron Healthcare Co. Ltd.

25. WHO (2011) Waist circumference and waist-hip ratio: report of a WHO expert consultation, Geneva, 8-11 December 2008. Geneva: WHO Press.

26. Aidar M, Line SR (2007) A simple and cost-effective protocol for DNA isolation from buccal epithelial cells. Braz Dent J 18:148-152.

27. Manchanda PK, Bid HK, Mittal RD (2005) Ethnicity greatly influences the Interleukin-1 gene cluster (IL-1 $\beta \beta$ Promoter, Exon-5 and IL-1Ra) polymorphisms: a pilot study of a 
North Indian population. Asian Pac J Cancer Prev 6:541-546.

28. Jiang J, Zhang X, Sun D, Jin Y, Bai J, Chen F, Fu S (2010) Study on VNTR polymorphism of gene IL-1Ra in 19 Chinese populations. Int J Immunogenet 37:73-77.

29. Parks CG, Cooper GS, Dooley MA, Treadwell EL, St Clair EW, Gilkeson GS, Pandey JP (2004) Systemic lupus erythematosus and genetic variation in the interleukin 1 gene cluster: a population based study in the southeastern United States. Ann Rheum Dis 63:91-94.

30. Vandenbrock K, Martino G, Marrosu MG Consiglio A, Zaffaroni M, Vaccargiu S, Franciotta D, Ruggeri M, Comi G, Grimaldi LM (1997) Occurrence and clinical relevance of an interleukin-4 gene polymorphism in patients with multiple sclerosis. J Neuroimmunol 76:189-192.

31. Huang D, Xia S, Zhou Y, Pirskanen R, Liu L, Lefvert AK (1998) No evidence of interleukin-4 gene conferring susceptibility to myasthenia gravis. J Neuroimmunol 92: 208-211.

32. Cantagrel A, Navaux F, Loubet-Lescoulie P Nourhashemi F, Enault G, Abbal M, Constantin A, Laroche M, Mazières B (1999) Interleukin-1b, interleukin-1 receptor antagonist, interleukin-4, and interleukin-10 gene polymorphisms. Relationship to occurrence and severity of rheumatoid arthritis. Arthritis Rheum 42:1093-1100.

33. Buchs N, Silvestri T, di Giovine FS, Chabaud M, Vannier E, Duff GW, Miossec P (2000) IL-4 VNTR gene polymorphism in chronic polyarthritis. The rare allele is associated with protection against destruction. Rheumatology 39:1126-1131.

34. Nakashima H, Miyake K, Inoue Y, Shimizu S, Akahoshi M, Tanaka Y, Otsuka T, Harada M (2002) Association between IL-4 genotype and IL-4 production in the Japanese population. Genes Immunity 3:107-109.

35. Vasudevan R, Norhasniza MN, Patimah I (2011) Association of variable number of tandem repeats polymorphism in the IL-4 gene with end-stage renal disease in Malaysian patients. Genet Mol Res 10:943-947.

36. Hurme M, Santtila S (1998) IL-1 receptor antagonist (IL-1Ra) plasma levels are coordinately regulated by both IL-1Ra and IL-1beta genes. Eur J Immunol 28:2598- 2602.

37. Um JY, Kim HM, Mun SW, Song YS, Hong SH (2006) Interleukin-1 recptor antagonist gene polymorphism and traditional classification in obese women. Int J Neurosci 116:3953.

38. Manchanda PK, Bid HK, Achyut BR, Mittal B, Srivastava N, Mittal RD (2007) Interleukin-1 receptor antagonist gene polymorphism and obesity: A pilot study from north India. Indian J Clin Biochem 22:61-64.

39. Hurme M, Helminen M (1998) Resistance to human cytomegalovirus infection may be influenced by genetic polymorphisms of the tumor necrosis factor-alpha and interleukin-1 receptor antagonist genes. Scand J Infect Dis 30:447-449.

40. Mustea A, Sehouli J, Konsgen D, Stengel D, Sofroni D, Lichtenegger W (2003) Interleukin 1 receptor antagonist (il- 1ra) polymorphism in women with cervical cancer. Anticancer Res 23:1099-1102. 
41. Mwantembe O, Gaillard MC, Barkhuizen M, Pillay V, Berry SD, Dewar JB, Song E (2001) Ethnic differences in allelic associations of the interleukin-1 gene cluster in South African patients with inflammatory bowel disease (IBD) and in control individuals. Immunogenet 52:249-254.

42. Salimi S, Mohammadoo-Khorasani M, Yaghmaei M, Mokhtari M, Moossavi M (2014) Possible association of IL-4 VNTR polymorphism with susceptibility to preeclampsia. BioMed Res Int 2014:497031.

43. A. Inanir, S. Tural, S. Yigit, Kalkan G, Pancar GS, Demir HD, Ates O (2013) Association of IL-4 gene VNTR variant with deep venous thrombosis in Behçet's disease and its effect on ocular involvement. Mol Vision 19:675-683.

44. Tsao CH, Shiau MY, Chuang PH, Chang YH, Huang J (2014) Interleukin-4 regulates lipid metabolism by inhibiting adipogenesis and promoting lipolysis. J Lipid Res 55:385-397.

45. Rao RR, Long JZ, White JP, Svensson KJ, Lou J, Lokurkar I, Jedrychowski MP, Ruas JL, Wrann CD, Lo JC, Camera DM, Lachey J, Gygi S, Seehra J, Hawley JA, Spiegelman BM (2014) Meteorin-like is a hormone that regulates immune-adipose interactions to increase beige fat thermogenesis. Cell. 157:1279-1291.

Table 1. Demographic and anthropometric characteristics of the subjects according to gender.

\begin{tabular}{|c|c|c|}
\hline Variables & Male $(n=128)$ & Female $(n=187)$ \\
\hline \multicolumn{3}{|l|}{ Ethnicity } \\
\hline Malay & $11(8.6)$ & $12(6.4)$ \\
\hline Chinese & $104(81.2)$ & $147(78.6)$ \\
\hline Indian & $13(10.2)$ & $28(15.0)$ \\
\hline$\chi^{2} ; p$ & \multicolumn{2}{|c|}{$1.91 ; 0.38$} \\
\hline \multicolumn{3}{|l|}{ BMI Class } \\
\hline Non-obese & $103(80.5)$ & $158(84.5)$ \\
\hline Obese & $25(19.5)$ & $29(15.5)$ \\
\hline$\chi^{2} ; p$ & \multicolumn{2}{|c|}{$0.87 ; 0.35$} \\
\hline \multicolumn{3}{|l|}{ WC Class } \\
\hline Normal & $104(81.2)$ & 147 (78.6) \\
\hline High & $24(18.8)$ & $40(21.4)$ \\
\hline$\chi^{2} ; p$ & \multicolumn{2}{|c|}{$0.33 ; 0.57$} \\
\hline \multicolumn{3}{|l|}{ TBF Class } \\
\hline Normal & $84(65.6)$ & $137(73.3)$ \\
\hline High & $44(34.4)$ & $50(26.7)$ \\
\hline$\chi^{2} ; p$ & \multicolumn{2}{|c|}{$2.12 ; 0.15$} \\
\hline
\end{tabular}

Parentheses indicate percentage (\%) within the same gender. 
Table 2. Association of IL1RA and IL4 VNTRs genotype and allele distribution with demographic and anthropometric classes.

\begin{tabular}{|c|c|c|c|c|c|c|c|c|c|c|c|}
\hline \multirow{2}{*}{$\begin{array}{l}\text { Genoty } \\
\text { pes/Alle } \\
\text { les }\end{array}$} & \multicolumn{2}{|c|}{ Gender } & \multicolumn{3}{|c|}{ Ethnicity } & \multicolumn{2}{|c|}{ BMI Class } & \multicolumn{2}{|c|}{ WC Class } & \multicolumn{2}{|c|}{ TBF Class } \\
\hline & Male & Female & Malay & Chinese & Indian & $\begin{array}{l}\text { Non- } \\
\text { obese }\end{array}$ & Obese & Normal & High & Normal & High \\
\hline \multicolumn{12}{|l|}{$I L 1 R A$} \\
\hline $\mathrm{I} / \mathrm{I}$ & $\begin{array}{c}124 \\
(96.9)\end{array}$ & $\begin{array}{c}177 \\
(94.7)\end{array}$ & $23(100)$ & $\begin{array}{c}245 \\
(97.6)\end{array}$ & $33(80.5)$ & $\begin{array}{c}250 \\
(95.8)\end{array}$ & $51(94.4)$ & $\begin{array}{c}241 \\
(96.0)\end{array}$ & $60(93.8)$ & $\begin{array}{c}218 \\
(98.6)\end{array}$ & $83(88.3)$ \\
\hline $\mathrm{I} / \mathrm{II}$ & $4(3.1)$ & $9(4.8)$ & 0 & $5(2.0)$ & $8(19.5)$ & $10(3.8)$ & $3(5.6)$ & $9(3.6)$ & $4(6.2)$ & $2(0.9)$ & $11(11.7)$ \\
\hline $\mathrm{II} / \mathrm{II}$ & 0 & $1(0.5)$ & 0 & $1(0.4)$ & 0 & $1(0.4)$ & 0 & $1(0.4)$ & 0 & $1(0.5)$ & 0 \\
\hline$\chi^{2} ; p$ & & & & & & NP & & & & & \\
\hline I & $\begin{array}{c}252 \\
(98.4)\end{array}$ & $\begin{array}{c}363 \\
(97.1)\end{array}$ & $46(100)$ & $\begin{array}{c}495 \\
(98.6)\end{array}$ & $74(90.2)$ & $\begin{array}{c}510 \\
(97.7)\end{array}$ & $\begin{array}{c}105 \\
(97.2)\end{array}$ & $\begin{array}{c}491 \\
(97.8)\end{array}$ & $\begin{array}{c}124 \\
(96.9)\end{array}$ & $\begin{array}{c}438 \\
(99.1)\end{array}$ & $\begin{array}{c}177 \\
(94.1)\end{array}$ \\
\hline II & $4(1.6)$ & $11(2.9)$ & 0 & $7(1.4)$ & $8(9.8)$ & $12(2.3)$ & $3(2.8)$ & $11(2.2)$ & $4(3.1)$ & $4(0.9)$ & $11(5.9)$ \\
\hline$p$ & \multicolumn{2}{|c|}{0.30} & \multicolumn{3}{|c|}{$\begin{array}{c}\text { M vs. C: } 1.00 ; \mathrm{M} v s . \mathrm{I}: 0.05 ; \mathrm{C} v s . \\
\mathrm{I}:<0.001^{*}\end{array}$} & \multicolumn{2}{|c|}{0.73} & \multicolumn{2}{|c|}{0.52} & \multicolumn{2}{|c|}{$0.001 *$} \\
\hline \multicolumn{12}{|l|}{ IL4 } \\
\hline $\mathrm{B} 1 / \mathrm{B} 1$ & $84(65.6)$ & $\begin{array}{c}108 \\
(57.8)\end{array}$ & $10(43.5)$ & $\begin{array}{c}167 \\
(66.5)\end{array}$ & $15(36.6)$ & $\begin{array}{c}160 \\
(61.3)\end{array}$ & $32(59.3)$ & $\begin{array}{c}153 \\
(61.0)\end{array}$ & $39(60.9)$ & $\begin{array}{c}141 \\
(63.8)\end{array}$ & $51(54.3)$ \\
\hline
\end{tabular}




$\begin{array}{lccccccccccc}\mathrm{B} 1 / \mathrm{B} 2 & 31(24.2) & 57(30.5) & 11(47.8) & 67(26.7) & 10(24.4) & 74(28.4) & 14(25.9) & 69(27.5) & 19(29.7) & 60(27.1) & 28(29.8) \\ \mathrm{B} 2 / \mathrm{B} 2 & 13(10.2) & 22(11.8) & 2(8.7) & 17(6.8) & 16(39.0) & 27(10.3) & 8914.8) & 29(11.6) & 6(9.4) & 20(9.0) & 15(16.0) \\ \chi^{2} ; p & 2.02 ; 0.37 & & \mathrm{NP} & & 0.93 ; 0.63 & 0.31 ; 0.86 & 3.98 ; 0.14 \\ \mathrm{~B} 1 & 199 & 273 & 31(67.4) & 401 & 40(48.8) & 394 & 78(72.2) & 375 & 97(75.8) & 342 & 130 \\ & (77.7) & (73.0) & & (79.9) & & (75.5) & & (74.7) & (77.4) & (69.1) \\ \mathrm{B} 2 & 57(22.3) & 101 & 15(32.6) & 101 & 42(51.2) & 128 & 30(27.8) & 127 & 31(24.2) & 100 & 58(30.9) \\ & & (27.0) & & (20.1) & (24.5) & & (25.3) & (22.6) \\ \chi^{2} ; p & 1.82 ; 0.18 & & 37.78 ;<0.001^{*} & 0.51 ; 0.48 & 0.06 ; 0.80 & 4.75 ; 0.03 *\end{array}$

Parentheses indicate percentage within the same demographic/anthropometric class; NP $=\chi^{2}$ Test not performed due presence of cell having the count of less than 5; $p$-values by $\chi^{2}$ or Fisher's Exact Test; * $p$-value significant at $<0.05$; $p$-values for ethnicity are combination analysis of Malay $v s$. Chinese, Malay $v s$. Indian, and Chinese $v s$. Indian. 
Table 3. Logistic regression analysis for the association of $I L-1 R a$ and $I L-4$ VNTRs with overall adiposity status.

\begin{tabular}{|c|c|c|c|c|}
\hline \multirow{2}{*}{$\begin{array}{l}\text { Genotype/ } \\
\text { Allele }\end{array}$} & \multicolumn{2}{|l|}{ Unadjusted } & \multicolumn{2}{|l|}{ Adjusted ${ }^{\S}$} \\
\hline & Odds ratio $(95 \% \mathrm{CI})$ & $p$ & Odds ratio $(95 \% \mathrm{CI})$ & $p$ \\
\hline \multicolumn{5}{|l|}{ ILIRA } \\
\hline $\mathrm{I} / \mathrm{I}$ & 1.00 & & 1.00 & \\
\hline $\mathrm{I} / \mathrm{II}$ & $14.45(3.14,66.56)$ & $0.001 *$ & $12.21(2.54,58.79)$ & $0.002 *$ \\
\hline II/II & NP & 1.00 & NP & 1.00 \\
\hline I & 1.00 & & 1.00 & \\
\hline II & $6.81(2.14,21.66)$ & $0.001 *$ & $5.78(1.73,19.29)$ & $0.004^{*}$ \\
\hline \multicolumn{5}{|l|}{ IL4 } \\
\hline $\mathrm{B} 1 / \mathrm{B} 1$ & 1.00 & & 1.00 & \\
\hline $\mathrm{B} 1 / \mathrm{B} 2$ & $2.07(0.99,4.36)$ & 0.05 & $1.32(0.57,3.06)$ & 0.53 \\
\hline $\mathrm{B} 2 / \mathrm{B} 2$ & $1.29(0.74,2.24)$ & 0.37 & $1.01(0.55,1.85)$ & 0.97 \\
\hline B1 & 1.00 & & 1.00 & \\
\hline $\mathrm{B} 2$ & $1.53(1.04,2.23)$ & $0.03 *$ & $1.13(0.74,1.74)$ & 0.57 \\
\hline
\end{tabular}

$\S$ Adjusted for co-variate ethnicity; Values are by logistic regression enter method; ${ }^{*} p$-value significant at $<0.05$ 
Table 4. Adjusted means of anthropometric measurements and blood pressures for different $I L-1 R a$ and $I L-4$ VNTRs alleles.

\begin{tabular}{|c|c|c|c|c|}
\hline \multirow[t]{2}{*}{ Variables } & \multicolumn{2}{|c|}{ ILIRA } & \multicolumn{2}{|c|}{ IL4 } \\
\hline & I & II & B1 & B2 \\
\hline WC & $77.16 \pm 0.48$ & $81.98 \pm 3.06$ & $79.59 \pm 1.59$ & $79.55 \pm 2.64$ \\
\hline$p$ & \multicolumn{2}{|c|}{0.09} & \multicolumn{2}{|c|}{0.99} \\
\hline BMI & $21.83 \pm 0.18$ & $23.26 \pm 1.12$ & $22.54 \pm 0.58$ & $22.55 \pm 0.97$ \\
\hline$p$ & \multicolumn{2}{|c|}{0.14} & \multicolumn{2}{|c|}{0.95} \\
\hline TBF & $23.51 \pm 0.40$ & $31.79 \pm 2.52$ & $26.09 \pm 1.31$ & $29.21 \pm 2.18$ \\
\hline$p$ & \multicolumn{2}{|c|}{$0.005^{*}$} & \multicolumn{2}{|c|}{0.34} \\
\hline SBP & $113.26 \pm 0.68$ & $108.95 \pm 4.32$ & $114.65 \pm 2.24$ & $107.56 \pm 3.73$ \\
\hline$p$ & \multicolumn{2}{|c|}{0.19} & \multicolumn{2}{|c|}{0.06} \\
\hline DBP & $68.81 \pm 0.41$ & $68.66 \pm 2.60$ & $68.22 \pm 1.35$ & $69.25 \pm 2.25$ \\
\hline$p$ & \multicolumn{2}{|c|}{0.68} & \multicolumn{2}{|c|}{0.37} \\
\hline
\end{tabular}

WHR: Waist-to-hip ratio; BMI: Body mass index; TBF: Total body fat; SBP: Systolic blood pressure; DBP: Diastolic blood pressure; All values were log transformed before analysis by univariate analysis of variance (General Linear Model), adjusted for co-variate ethnicity; Values are presented as adjusted mean \pm SEM (estimated marginal means \pm standard error of the mean); ${ }^{*} p$-value significant at $<0.05$. 